\section{Biorefinery-Biobased Value Chains and Sustainable Development}

\author{
8-12 September 2013, Olsztyn, Poland
}

The concept of a biorefinery generating a spectrum of biomass-based products arranged in a value chain is the biggest research challenge for the next decades. First, the development of this concept requires an interdisciplinary research approach. Second, applied research effects associated with biorefineries, new biorefinery processes, and products implemented in the future will integrate three fundamental areas of sustainable development: economy, environment, and society.

The 4th International Environmental Best Practices
Conference "Biorefinery-Biobased Value Chains and Sustainable Development" will summarize research achievements and new trends in many interrelated aspects associated with biorefinery processes and products. They will be discussed in the eight consecutive research panels of session presentations and posters:

1. Biorefinery-Research Progress and Opportunities

2. Feedstock

3. Genetics and Biotechnology

4. Biomass Pretreatment

5. Bioprocesses and Bioproducts

6. Valorization of Waste, Effluents and By-products by Microorganisms and Enzymes

7. Thermal, Chemical and Biochemical Conversion of Biomass to Useful Energy

8. Environmental Impact

www.ebp4.pl

See Mark Your Calendar for contact information.

(200 words maximum) and full papers (A-4 typed double spaced, and 8 pages maximum) by email to loctechnical@chemsocnigeria.org.

All papers are to be peer-reviewed, and accepted papers will be published in the conference proceedings. The deadline for the submission of abstracts is 9 July 2013 and for the submission of full papers is 19 July 2013.

Siil- http://chemsocnigeria.org

on the issues caused by the Fukushima Daiichi Nuclear Power Plant accident in March 2011 will be also organized. The APSORC 13 is co-organized by The Japan Society of Nuclear and Radiochemical Sciences and Kanazawa University.

Siil www.apsorc13.org

See Mark Your Calendar for contact information. 